\title{
What can cell cycle and ultrastructure tell us about desiccation tolerance in Leucaena leucocephala germinating seeds?
}

\author{
J. MAIA ${ }^{1 *}$, C.C. GUIMARÃES ${ }^{2}$, E.A.A. DA SILVA ${ }^{1}$, and J.M.R. FARIA ${ }^{2}$ \\ São Paulo State University, FCA/UNESP, CEP 18610-307, Botucatu, SP, Brazil ${ }^{1}$ \\ Departament of Forest Sciences, Federal University of Lavras, CEP 37200-000, Lavras, MG, Brazil ${ }^{2}$
}

\begin{abstract}
Desiccation tolerance (DT) is the ability to tolerate dehydration to levels below $0.1 \mathrm{~g}\left(\mathrm{H}_{2} \mathrm{O}\right) \mathrm{g}^{-1}(\mathrm{dry}$ mass $)$ and subsequent rehydration without lethal damage. Here, it is proposed that Leucaena leucocephala, a tree species, has potential to be model tolerant species in seed research. Using flow cytometry and transmission electron microscopy, cytological changes related to loss of DT in Leucaena primary roots were followed during germination. Leucaena seeds lost their DT at the end of germination and this coincided with an increase in cellular 4C DNA content. A negative correlation between the $8 \mathrm{C}$ DNA content and the capacity of germinating Leucaena seeds to tolerate desiccation was also observed. Apparently, the seeds of Leucaena underwent extra cycles of endoreduplication and accumulated a high content of DNA - an event not previously linked to DT. The ultrastructural damage imposed by drying overcame Leucaena primary root cell resilience and their ability to resume normal growth. Nuclear DNA content may be used as indicator of progress of germination and loss of DT in Leucaena.
\end{abstract}

Additional key words: DNA content, endoreduplication, flow cytometry, transmission electron microscopy.

\section{Introduction}

Desiccation tolerant organisms are able to dehydrate to water content below $0.1 \mathrm{~g}\left(\mathrm{H}_{2} \mathrm{O}\right) \mathrm{g}^{-1}$ (d.m.), rehydrate, and resume normal growth (Oliver et al. 2000, Phillips et al. 2002). Ability to tolerate desiccation is common feature of angiosperm seeds (orthodox seeds; Potts 1994, Dinakar and Bartels 2013). Such seeds acquire desiccation tolerance (DT) during seed development and maturation (Bewley et al. 2013). After dispersal or harvest, DT remains during storage or in the soil seed bank. Once water is available, orthodox seeds imbibe and germinate if non-dormant. With progress of germination, such seeds gradually lose DT becoming completely desiccation sensitive around the point of radicle protrusion (Bewley et al. 2013). Desiccation tolerance in seeds has been studied over the past few decades with a particular emphasis on its acquisition during seed maturation (Blackman et al. 1992, Black et al. 1999, Sreedhar et al. 2002, Illing et al. 2005, Verdier et al. 2013). Association of DT with accumulation of sugars, late embryogenesis abundant proteins, and activity of antioxidant scavenging systems have been extensively reported (Blackman et al. 1992, Bailly 2004, Buitink and
Leprince 2004, Kranner and Birtic 2005, Tunnacliffe and Wise 2007, Hundertmark et al. 2011, Dinakar and Bartels 2013). A less explored aspect of DT is its loss during germination in seeds of tropical tree species and cellular adjustments related to it.

Ultrastructural modifications and the cell cycle (DNA content) have been associated with desiccation sensitivity in seeds (Berjak and Pammenter 2000, Berjak and Pammenter 2008). For example, ultrastructural stabilizing processes, such as plasmalemma displacement and intracellular space vacuolization, are common features observed in DT tissues under dehydration stress (Farrant 2000, Berjak and Pammenter 2008, Moore et al. 2008). Progression of the cell cycle is considered a good marker for DT (Faria et al. 2005) and it is hypothesized that cells in the $\mathrm{G} 1$ phase of the cell cycle (2C nuclei) are more resistant to stress and have a greater longevity than cells in the G2 phase (4C nuclei) (Saracco et al. 1995, Faria et al. 2005). Endoreduplication, resulting in ploidy levels equal or higher than $4 \mathrm{C}$, have been correlated to a larger cell size and connected with reserve deposition in seeds (Lemontey et al. 2000, Atif et al. 2013) and salt and

Submitted 28 April 2015, last revision 17 August 2015, accepted 5 October 2015.

Abbreviations: DT - desiccation tolerance; TEM - transmission electron microscopy; WC - water content.

Acknowledgments: This research was supported by the Coordenação de Aperfeiçoamento de Pessoal de Nível Superior (CAPES), Brazil.

* Corresponding author: juliomaia2@gmail.com 
osmotic stress tolerance (Elmaghrabi et al. 2013, Skirycz et al. 2011). However, to our knowledge, endoreduplication resulting in ploidy levels equal or higher than $8 \mathrm{C}$ has not been linked to DT or sensitivity in seeds.

Here, the seeds from a pantropical tree species Leucaena leucocephala (Lam.) De Wit were used as system to investigate DT and sensitivity in plants. Leucaena annually produces large amounts of orthodox

\section{Materials and methods}

Leucaena seeds were collected in the vicinity of Lavras (Minas Gerais, Brazil) from at least 20 trees. All seeds were pooled, air-dried, and stored in plastic bags at $10{ }^{\circ} \mathrm{C}$ and a $40 \%$ relative humidity. Previous assays revealed that Leucaena seeds exhibit physical, coat-imposed dormancy. To overcome this dormancy, mechanical scarification was performed prior to germination assays using sand paper, followed by immersion in distilled $\mathrm{H}_{2} \mathrm{O}$ at $25{ }^{\circ} \mathrm{C}$ for $16 \mathrm{~h}$. Germination tests were performed at $25^{\circ} \mathrm{C}$ and a constant irradiance of $26 \mu \mathrm{mol} \mathrm{m} \mathrm{m}^{-2} \mathrm{~s}^{-1}$ and determined from four independent replicates of 25 seeds using radicle protrusion as criterion for germination. Germination was carried out in standing paper rolls moistened with distilled water. Loss of DT and its dynamics after germination were determined by drying Leucaena seeds with a primary root of 1,3 , or $5 \mathrm{~mm}$ long. Four replicates of 20 seedlings for each stage were dried for $3 \mathrm{~d}$ over an activated silica gel in a closed box with a forced air flow at $20{ }^{\circ} \mathrm{C}$ until a water content of $1.0,0.67,0.43,0.25$ and $0.08 \mathrm{~g}\left(\mathrm{H}_{2} \mathrm{O}\right) \mathrm{g}^{-1}(\mathrm{~d} . \mathrm{m}$.) was reached. Water content was expressed on a dry mass basis (Cromarty et al. (1985). After dehydration, the germinated seeds were immediatelly pre-humidified at a $100 \%$ relative humidity and at $25^{\circ} \mathrm{C}$ for $24 \mathrm{~h}$ in the dark to avoid imbibitional damage (Leopold and Vertucci 1986) and rehydrated as previouslly described. Germinated seeds that continued their development and transformed into viable seedlings were considered desiccation-tolerant. Primary root survival and lateral root development were also evaluated.

Water content (WC) of dried seeds and germinated seeds with increasing protruded primary root length $(1,3$, and $5 \mathrm{~mm}$ ) was assessed in four replicates of 30 seeds by oven drying at $103 \pm 2{ }^{\circ} \mathrm{C}$ for $17 \mathrm{~h}$. The water content was expressed as $\mathrm{g}\left(\mathrm{H}_{2} \mathrm{O}\right) \mathrm{g}^{-1}$ (d.m.). Imbibition pattern was assessed in 3 replicates of 10 seeds which were mechanically scarified, soaked in distilled water, and germinated as described above. After imbibition/ germination, water content was estimated. To evaluate seedling formation, Leucaena germinated seeds with a $3 \mathrm{~mm}$ primary root length were dehydrated up to $1.0,0.67,0.43$, and $0.25 \mathrm{~g}\left(\mathrm{H}_{2} \mathrm{O}\right) \mathrm{g}^{-1}(\mathrm{~d} . \mathrm{m}$.$) , pre-$ humidified, and rehydrated as previously described. Seedling fresh mass was evaluated after $7 \mathrm{~d}$. seeds, which have an easily breakable seed coat and normally reach high germination percentages. Such characteristics make Leucaena a potential model species in tree seed research. Using techniques such as flow cytometry and transmission electron microscopy, cytological changes related to loss of DT in Leucaena primary roots during and after germination were explored.

Relative DNA content was assessed by flow cytometry of intact nuclei prepared from radicles excised from seeds after 16, 24, 40, and $44 \mathrm{~h}$ of imbibition. Samples were prepared according to Carvalho et al. (2008) and analyzed on a Partec PAS flow cytometer (Partec ${ }^{\circledR}$, Munster, Germany) equipped with a laser source and a series of filters ( $T K$ 420, TK 560, and $R G 610)$. Each replicate was processed with no less than 5000 nuclei. Samples with variation coefficients greater than $5 \%$ were discarded and re-evaluated.

For transmission electron microscopy (TEM) analysis, samples of $3 \mathrm{~mm}$ long primary roots, fresh with $2.03 \mathrm{~g}\left(\mathrm{H}_{2} \mathrm{O}\right) \mathrm{g}^{-1}$ (d.m.) and dried with 0.43 and 0.09 $\mathrm{g}\left(\mathrm{H}_{2} \mathrm{O}\right) \mathrm{g}^{-1}$ (d.m.), and radicles excised directly from control dry seeds with $0.09 \mathrm{~g}\left(\mathrm{H}_{2} \mathrm{O}\right) \mathrm{g}^{-1}$ (d.m.), were cut transversally and immersed in a modified Karnovsky fixative solution containing $2.5 \%(\mathrm{~m} / \mathrm{v})$ glutaraldehyde, $2 \%(\mathrm{~m} / \mathrm{v})$ formaldehyde, a $0.05 \mathrm{M}$ sodium cacodylate buffer, and $0.001 \mathrm{M} \mathrm{CaCl}_{2}(\mathrm{pH} 7.2)$ and stored in a cold chamber $\left(4^{\circ} \mathrm{C}\right)$ until analysis. The samples were washed in a $0.05 \mathrm{M}$ cacodylate buffer three times for $10 \mathrm{~min}$, post-fixed in a $1 \%(\mathrm{~m} / \mathrm{v})$ aqueous osmium tetroxide solution for $1 \mathrm{~h}$, washed twice for $15 \mathrm{~min}$ in distilled water, transferred to a $0.5 \%(\mathrm{~m} / \mathrm{v})$ uranyl acetate solution $\left(4^{\circ} \mathrm{C}\right)$ for $12 \mathrm{~h}$, and finally washed once more in distilled water and dehydrated in a series of acetone solutions $[25,50,75,90$ and $100 \%(\mathrm{v} / \mathrm{v})]$ three times. The dehydrated tissue was gradually infiltrated with Spurr epoxy resin [Spurr/acetone, $30 \%$ for $8 \mathrm{~h}, 70 \%$ for $12 \mathrm{~h}$ and $100 \%(\mathrm{~m} / \mathrm{v})$ twice for $24 \mathrm{~h}$ each]. The specimens obtained were set in molds and polymerized at $70{ }^{\circ} \mathrm{C}$ for $48 \mathrm{~h}$ forming blocks. The blocks were trimmed using a diamond knife in a Reichart-Jung ultramicrotome. Ultrathin sections $(<100 \mathrm{~nm})$ were selected using a gold ring, placed on glass microscope slides, stained with toluidine blue $\left(1 \mathrm{~g}\right.$ of toluidine blue, $1 \mathrm{~g}$ of $\mathrm{Na}_{2} \mathrm{~B}_{4} \mathrm{O}_{7} \cdot 10 \mathrm{H}_{2} \mathrm{O}$ and $100 \mathrm{~cm}^{3}$ of $\mathrm{H}_{2} \mathrm{O}$, filtered with a Millipore filter $(0.2 \mathrm{~mm})$ and mounted in Permalt. The ultra-thin sections were collected on gold slot grids and dried on aluminium racks coated with Formvar. The contrast of the sections was improved by staining in uranyl acetate followed by lead citrate for $3 \mathrm{~min}$ and then examined with a transmission electron microscope (TEM) (Zeiss EM-109) operating at $80 \mathrm{kV}$. 


\section{Results and discussion}

Understanding dynamics of germination and simultaneous or subsequent loss of DT in orthodox seeds creates opportunities for examining how organisms tolerate desiccation stress (Bruggink and Van der Toorn 1995, Buitink et al. 2003, 2006, Maia et al. 2011, 2014). By observing changes in nuclear DNA content and ultrastructural modifications, this study provides insights into mechanisms underlying sensitivity to drought and desiccation in Leucaena seeds.
Like most species of the Leguminosae family, Leucaena produces seeds which have dormancy imposed by an impervious tegument (Rolston 1978, Baskin and Baskin 1998). If properly treated for dormancy release, the seeds of Leucaena could achieve high germination indexes and synchronization when compared with nontreated seeds (Fig. 1A). The Leucaena seeds were dispersed with a low water content of approximately $0.14 \mathrm{~g}\left(\mathrm{H}_{2} \mathrm{O}\right) \mathrm{g}^{-1}$ (d.m.) and tolerated drying prior to

Table 1. Water content $\left[\mathrm{g}\left(\mathrm{H}_{2} \mathrm{O}\right) \mathrm{g}^{-1}(\mathrm{~d} . \mathrm{m})\right]$ of Leucaena seeds at different developmental stages and conditions. Means $\pm \mathrm{SEs}, n=4$.

Samples

Water content

Dry seeds from the seed batch

Dry seeds further dried above silica gel for $3 \mathrm{~d}$

Germinated seeds (1 $\mathrm{mm}$ primary root lengh)

Germinated seeds ( $3 \mathrm{~mm}$ primary root lengh)

Germinated seeds (5 $\mathrm{mm}$ primary root lengh)
$0.13 \pm 0.002$
$0.08 \pm 0.004$
$1.93 \pm 0.012$
$1.97 \pm 0.006$
$2.12 \pm 0.013$

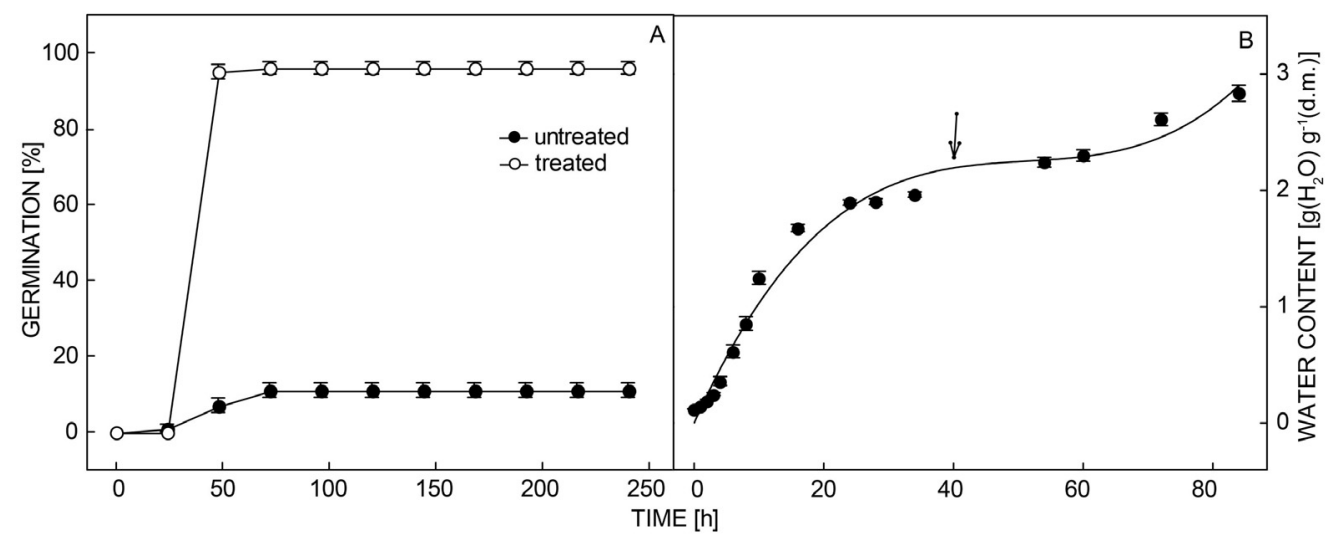

Fig. 1. Time course of germination and water content during imbibition of Leucaena seeds at $25^{\circ} \mathrm{C}$. Seeds treated with scarification (open circles) or untreated (closed circles). Means $\pm \mathrm{SEs}, n=4(A)$ or $10(B)$. The arrow indicates the point of radical protrusion.

storage down to $0.07 \mathrm{~g}\left(\mathrm{H}_{2} \mathrm{O}\right) \mathrm{g}^{-1}$ (d.m.) without loss of viability. The fully imbibed Leucaena seeds with primary root lengths of 1,3 , and $5 \mathrm{~mm}$ reached water content of 1.93, 1.98, and $2.12 \mathrm{~g}\left(\mathrm{H}_{2} \mathrm{O}\right) \mathrm{g}^{-1}$ (d.m.), respectively (Table 1). The imbibition pattern found for the Leucaena seeds (Fig. 1B) matched a pattern described by Bewley and Black (1994). This pattern is characterized by a rapid initial uptake of water (phase I), followed by a stationary phase (phase II) which culminates in a marked increase in fresh mass due to radicle protrusion and elongation. The point corresponding to the radicle protrusion occurred $40 \mathrm{~h}$ after the beginning of imbibition (Fig. 1B). The germinated seeds at different developmental stages exhibited similar rates of water loss and achieved similar water content by the end of drying (Fig. 2).

To relate developmental stages after germination with DT in a more accurate way, the germinated seeds at precise developmental stages with primary root lengths of 1,3 , and $5 \mathrm{~mm}$ were sampled and analyzed. These seeds

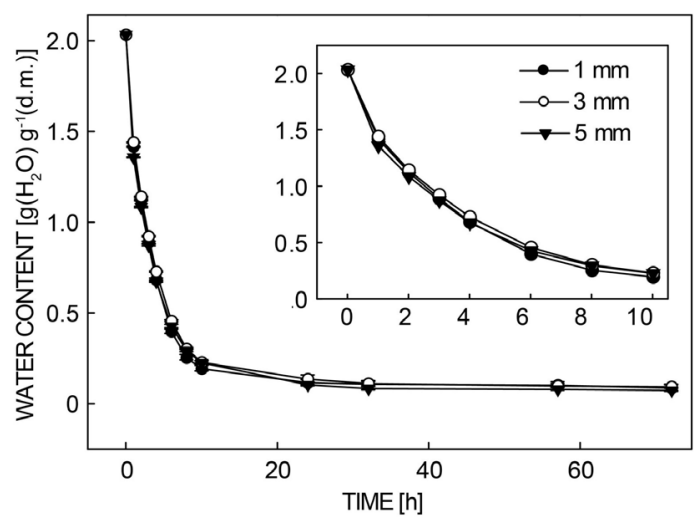

Fig. 2. Water content changes of Leucaena seeds upon dehydration above dry silica gel. Germinated seeds with a primary root length of $1 \mathrm{~mm}$ (closed circles), $3 \mathrm{~mm}$ (open circles), and $5 \mathrm{~mm}$ (triangles). The inset depicts the first hours of drying in more detail. Means \pm SEs, $n=4$. 
were dehydrated to different water content ranging from 2.15 to $0.07 \mathrm{~g}\left(\mathrm{H}_{2} \mathrm{O}\right) \mathrm{g}^{-1}$ (d.m.) and evaluated for their survival, i.e., an ability to resume normal growth after being dehydrated and rehydrated as well as for survival of their primary roots and secondary root development (Fig. 3). Desiccation tolerance was completely lost around the point of radicle protrusion. The majority of the seeds in all developmental stages did not tolerate drying to a water content of $0.07 \mathrm{~g}\left(\mathrm{H}_{2} \mathrm{O}\right) \mathrm{g}^{-1}$ (d.m.) (Fig. 3). Only $16 \%$ of the seeds with a $1 \mathrm{~mm}$ root survived, and no survival was observed for those with a primary root length of 3 and $5 \mathrm{~mm}$ (Fig. $3 A, B, C$ ). In addition, the more germinated seed, the quicker loss of root viability in relation to drying (Fig. $3 A, B, C$ ). Together, these data suggest a developmental stage-dependent sensitivity to desiccation. Noticeably, more seedlings survived due to secondary root formation (Fig. 3A,B,C,D and Fig. 4A,B), a phenomenon also observed by other authors (Koster and Leopold 1988, Bruggink and Van der Toorn 1995, Vieira et al. 2010, Maia et al. 2011). Although all

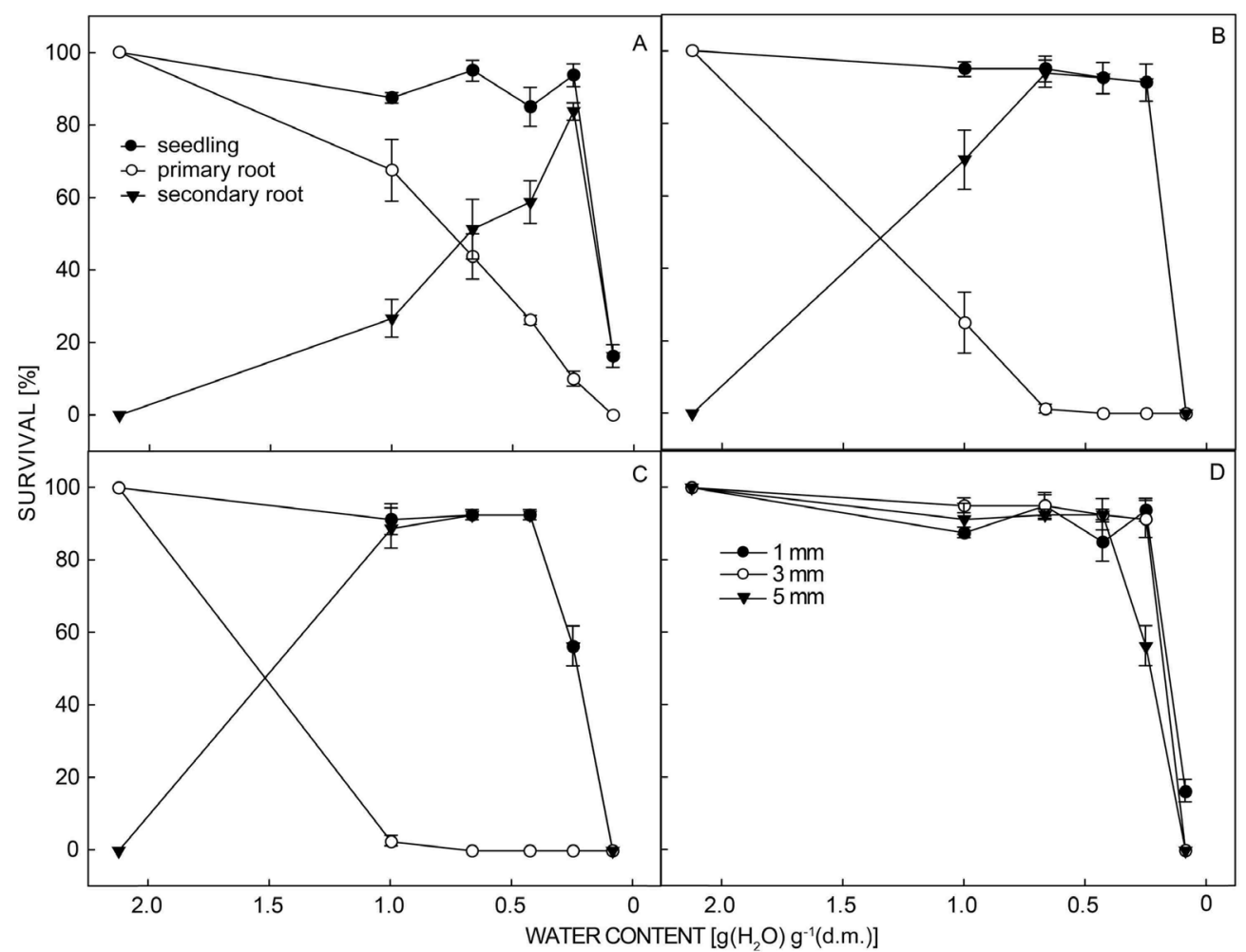

Fig. 3. Loss of desiccation tolerance in germinated Leucaena seeds dried to a different water content. Seeds with primary roots of $1 \mathrm{~mm}(A), 3 \mathrm{~mm}(B)$, and $5 \mathrm{~mm}(C)$, and seedling formation $(D)$. Means \pm SEs, $n=4$.
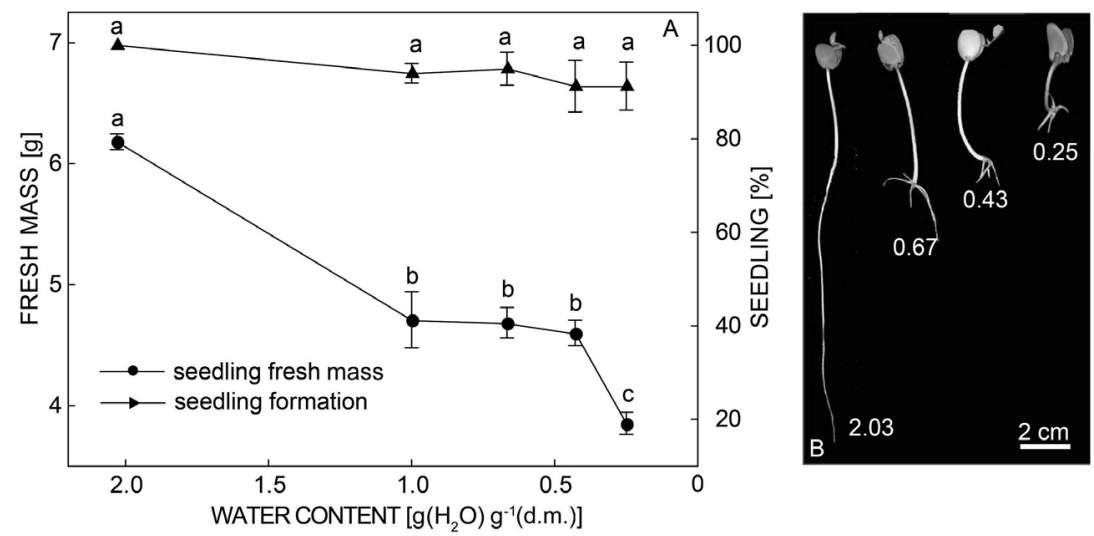

Fig. 4. Seedling formation and growth in Leucaena seeds subjected to different dehydration stresses. $A$ - Seedling formation (triangles) and fresh mass (circles) upon different dehydration stresses. Fresh mass was measured $7 \mathrm{~d}$ after rehydration. Means \pm SEs, $n=4$; different letters represent significant differences at $P \leq 0.05$ between data points in the same curve. $B$ - Appearance of dehydrated and hydrated Leucaena seedlings after $7 \mathrm{~d}$. After dehydration to $0.67 \mathrm{~g}\left(\mathrm{H}_{2} \mathrm{O}\right) \mathrm{g}^{-1}(\mathrm{~d} . \mathrm{m}$.), most seedlings developed secondary roots to compensate for the loss of their primary root. 
germinated seeds, independently of the developmental stage, had high survival rates when dried to water content higher or equal to $0.25 \mathrm{~g}\left(\mathrm{H}_{2} \mathrm{O}\right) \mathrm{g}^{-1}$ (d.m.) (Fig. $3 D$ ), a gradual reduction in seedling fresh mass was evident (Fig. $4 A$ ) showing a gradual loss of DT along drying. The point where DT begins to be lost, taking into account the imbibition time and primary root length after radicle protrusion, varies from species to species. Nevertheless, other factors such as onset of the cell cycle may be relevant for seed desiccation tolerance. It has been suggested that nuclear DNA content is directly related to sensitivity to stress responses and phase transitions on seeds where a higher or lower DNA content can positively or negatively influence the sensitivity to a stress or speed of seed germination (Saracco et al. 1995, Lemontey et al. 2000, Sliwinska 2003, Faria et al. 2005, Atif et al. 2013). The flow cytometry analysis of Leucaena dissected root tips before, during, and after germination indicates the existence of nuclei $2 \mathrm{C}, 4 \mathrm{C}$, and 8C (Fig. 5 and Fig. 1 Suppl.). Most of the nuclei measured during imbibition and after radicle protrusion had 2C DNA content (Fig. $5 A$ ) indicating that most of the evaluated cells were at the G1 phase of the cell cycle. The root tips isolated from the dry seeds displayed the lowest 4C DNA content indicating, as expected, small changes in the cell replication profile. The increase in sensitivity to dehydration observed in the Leucaena seeds under and after the visible germination coincided with an increase in 4C DNA content in primary root cell nuclei (Fig. 5B). These data indicate that at the end of maturation, two blocks may be acting on the cell cycle. The first works maintaining cells in the $\mathrm{G} 1 / \mathrm{S}$ phase (2C DNA, a presynthetic phase of the cell cycle), whereas the second prevents G2 phase cells (4C DNA) from progressing into mitosis. Similar results were found by Faria et al. (2005) who demonstrated that radicles from mature embryos of Medicago truncatula also contain relatively high 4C DNA content (45\%). Although some species show a high $4 \mathrm{C}$ DNA content, this is not a prevalent situation found in embryos of mature orthodox seeds. Generally, the majority of cells in mature quiescent embryos have $2 \mathrm{C}$ DNA content reflecting their retention in the $\mathrm{G} 1$ phase of the cell cycle (Deltour 1985, Bino et al. 1993, De Castro et al. 2000). Similarly as in Leucaena, an increase in 4C DNA content also marks germination progress in seeds of Lycopersicon esculentum, Capsicum annuum, Pinus banksiana, Beta vulgaris, Coffea arabica, Hordeum vulgare, and many other species (Sliwinska 2009).

A negative correlation between the $8 \mathrm{C}$ DNA content and the capacity of germinating Leucaena seeds to tolerate desiccation was also observed (Fig. 5C). Apparently, the seeds of Leucaena underwent extra cycles of endoreduplication and accumulated a greater DNA content in their cells. This observation may indicate that endoreduplication cycles may interfere with tolerance to certain abiotic stresses. Endoreduplication is well documented in endosperm and cotyledons of developing seeds, but its physiological significance is poorly understood. Endoreduplication principally influences cell size and elongation (e.g., seed development and germination), nutrient storage (e.g., cotyledons) and metabolic activity (Atif et al. 2013, Dante et al. 2014, Edgar et al. 2014). The association of endoreduplication with stress tolerance or sensitivity is less evident. Nevertheless, some studies support an idea that certain stresses, like osmotic stress acting via abscisic acid, could act by inhibiting endoreduplication (Wang et al. 1998, Setter and Flannigan 2001). On the other hand, a recent review by Ochatt (2015) collected information that supports a role for abscisic acid in inducing a cell division arrestment, whereas still allowing DNA replication in developing embryos, thus promoting

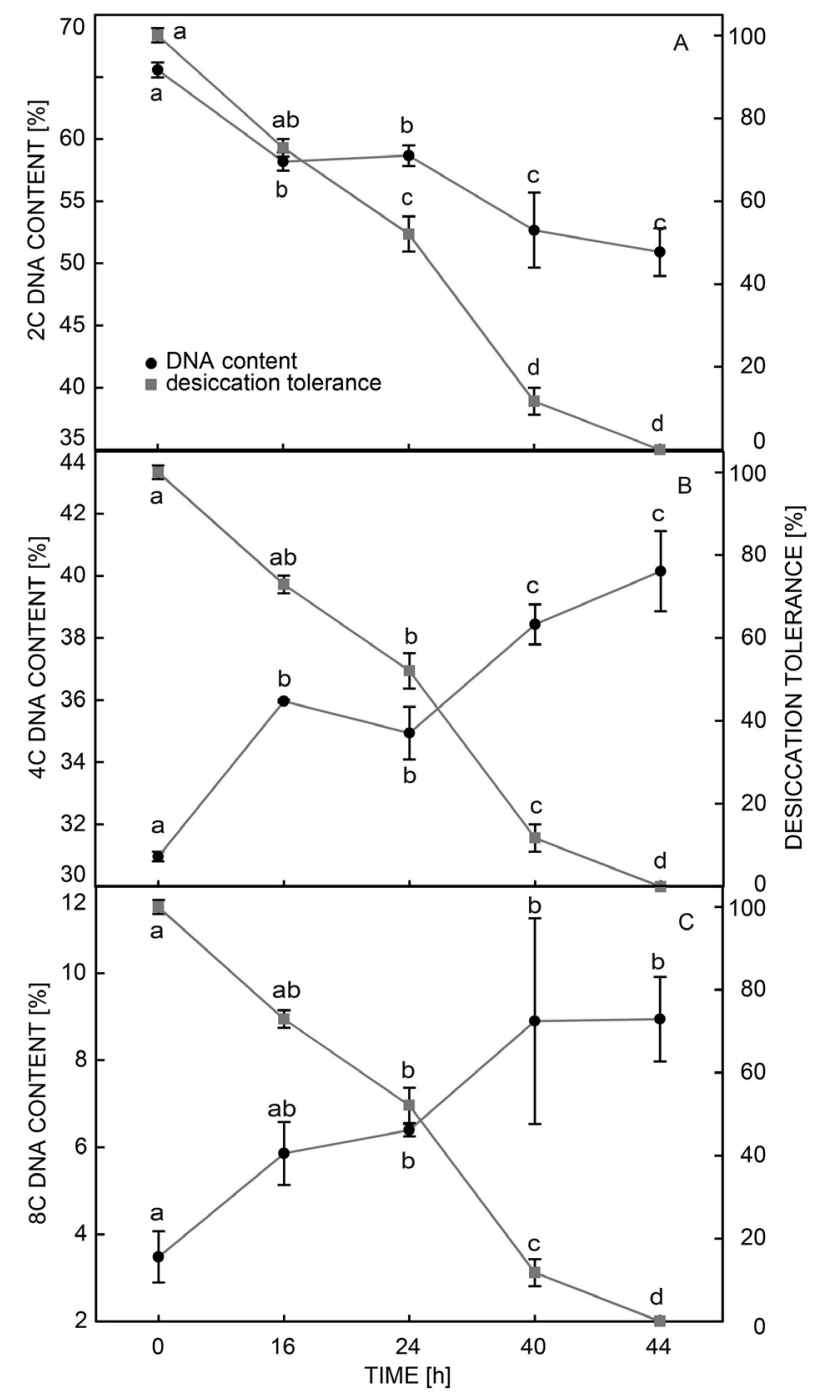

Fig. 5. Nuclear DNA content and desiccation tolerance in Leucaena seeds. Nuclear DNA content 2C $(A), 4 \mathrm{C}(B)$, and 8C (C) of excised Leucaena radicles (circles) versus desiccation tolerance (squares) of Leucaena seeds during and after germination. At a time point of $44 \mathrm{~h}$, seeds had a $1 \mathrm{~mm}$ radicle. Desiccation tolerance is expressed as the percentage of seeds that showed primary root survival. Means \pm SEs, $n=4$; different letters represent significant differences at $P \leq 0.05$ between data points in the same curve. 
endoreduplication. In addition, it has been shown that the expression of CCS52, a gene that controls the cell cycle switch, was up-regulated in Medicago truncatula calli subjected to salt stress and coincided with the onset of endoreduplication and the acquisition of tolerance to water and ionic stresses (Elmaghrabi et al. 2013). Together, those findings indicate a positive role for endoreduplication and stress tolerance at least in embryogenic calli and during seed development. In Leucaena, endoreduplication apparently indicates progression of germination and could be a compensatory response to associated stresses experienced during germination (e.g., oxidative stress caused by radicle protrusion). Consequently, a greater genome copy number caused by increased endoreduplication at the end of germination might be detrimental in the case of severe stresses like desiccation, thus contributing to a reduced capacity to tolerate drying observed in the Leucaena germinated seeds.
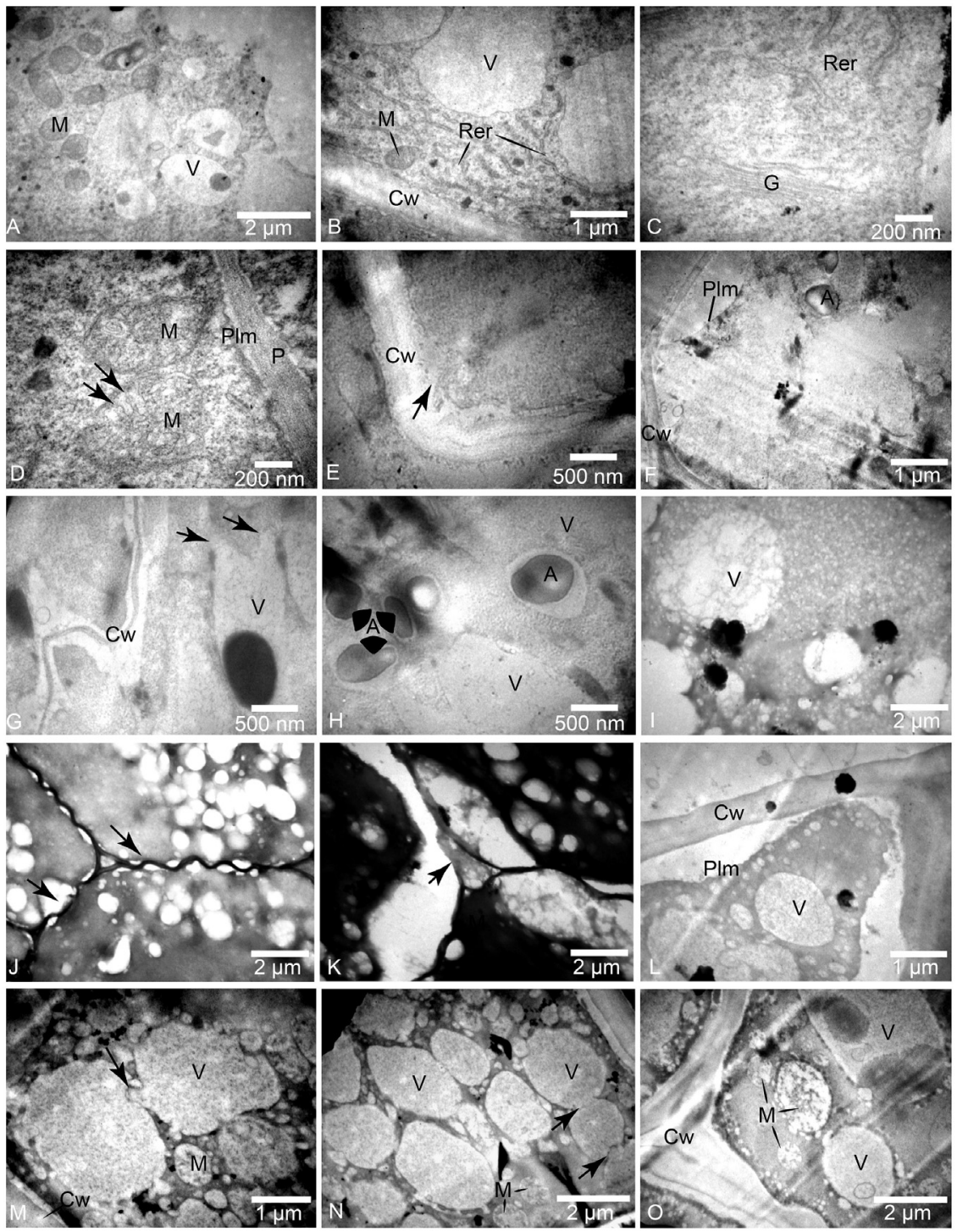

Fig. 6. Ultrastructural changes in Leucaena seeds subjected to different dehydration stresses. Transmission electron micrographs of $3 \mathrm{~mm}$ long primary roots excised from fresh $\left[2.03 \mathrm{~g}(\mathrm{H} 2 \mathrm{O}) \mathrm{g}^{-1}(\right.$ d.m. $\left.)\right](A, B, C, D)$ and dried to $0.43 \mathrm{~g}\left(\mathrm{H}_{2} \mathrm{O}\right) \mathrm{g}^{-1}(\mathrm{~d} . \mathrm{m}$. $)(E, F, G, H)$ or $0.09 \mathrm{~g}\left(\mathrm{H}_{2} \mathrm{O}\right) \mathrm{g}^{-1}$ (d.m.)] $(I, J, K)$, and from radicles excised directly from non-germinated dried seeds further dried to $0.07 \mathrm{~g}\left(\mathrm{H}_{2} \mathrm{O}\right) \mathrm{g}^{-1}$ (d.m.) $(L, M, N, O)$. Mitochondria $(\mathrm{M})$, vacuoles $(\mathrm{V})$, cell wall $(\mathrm{Cw})$, Golgi body $(\mathrm{G})$, rough endoplasmic reticulum (Rer), plasmalemma (Plm), and amyloplast (A) are shown. Arrows indicate mitochondrial cristae $(D)$, plasmallemma rupture $(E)$, vacuole rupture $(G)$, convoluted cell wall $(J)$, cell wall rupture $(K)$, and vacuole fusion $(M)$.

Microscopy has proved to be a useful tool to investigate the extent of damage to seeds under various stresses. Here, the samples obtained from $3 \mathrm{~mm}$ long primary roots of Leucaena [fresh, $2.12 \mathrm{~g}\left(\mathrm{H}_{2} \mathrm{O}\right) \mathrm{g}^{-1}(\mathrm{~d}$.m.), and dried to 0.43 and $0.07 \mathrm{~g}\left(\mathrm{H}_{2} \mathrm{O}\right) \mathrm{g}^{-1}(\mathrm{~d} . \mathrm{m}$.) ] as well as from radicles excised directly from non-germinated dry 
seeds were analyzed. In general, fully hydrated radicle cells displayed a high number of well-differentiated mitochondria, strong profiles of rough endoplasmic reticulum, and a prominent Golgi apparatus (Fig. $6 A, B, C, D)$ indicating the presence of an active metabolism. The plasmalemma was also intact and adhered to the cell wall (Fig. 6D). As soon as the germinated seeds were progressively dehydrated, their radicle cells became vacuolated and were extensively damaged (Fig. $6 E, F, G, H$ ). Most of the organelles disappeared, few mitochondria, apparently degraded, were observed (data not shown), and amyloplasts became less electron-dense (Fig. 6H). Cytoplasm contraction led by the reduction of water content caused the cell membrane to separate from the cell wall and the collapse of its trilaminar structure (Fig. $6 E, F)$. When dried to $0.07 \mathrm{~g}\left(\mathrm{H}_{2} \mathrm{O}\right) \mathrm{g}^{-1}$ (d.m.), the primary root cells experienced an extreme damage and total collapse of their intracellular structure. The cytoplasm was electron-dense, indistinct and, in some cells, it became granular (Fig. 6I). Besides, many cells had numerous vacuoles of a small size, almost no organelles were discernible. The cell membrane was disrupted and detached from the cell wall, which was thin convoluted, and ruptured at some points (Fig. 6J,K). Opposite, radicle cells of non-germinated seeds (DT) taken directly from storage and dried to $0.07 \mathrm{~g}\left(\mathrm{H}_{2} \mathrm{O}\right) \mathrm{g}^{-1}$ (d.m.) showed a relatively organized intracellular space (Fig. $6 L, M, N, O$ ). Although those radicles were completely dry, it was still possible to observe some organelles such as mitochondria with poorly developed cristae (Fig. $6 \mathrm{M}, \mathrm{N}, \mathrm{O}$ ) and the presence of large vacuoles (Fig. $6 M, N)$. The plasmalemma was detached in relation to the cell wall, however, no extensive damage to its trilaminar structure was present (Fig. 6L).

Apparently, two strategies to avoid further damage took place in Leucaena seeds. First, under the intermediate dehydration level, most of the organelles related to an active metabolism, such as the Golgi apparatus, rough endoplasmic reticulum, and mitochondria, were degraded. The dismantlement of these organelles might serve to arrest development and to minimize oxidative damage caused by reactive oxygen species production. Second, under the lower water content, mechanical protection strategies, such as cell wall convolution, cell membrane displacement, and intense vacuolization, had to take place to prevent cell collapse. As observed in the radicle tips of the nongerminated dry Leucaena seeds, the displacement of the cell wall membrane caused by cytoplasm retraction in response to dehydration could be linked to the ability to tolerate drying. This response ensured membrane integrity maintenance during the dry stage. On the other hand, when germinated seeds were dried to $0.07 \mathrm{~g}\left(\mathrm{H}_{2} \mathrm{O}\right) \mathrm{g}^{-1}$ (d.m.), the ultrastructural damage they experienced compromised their tolerance mechanisms. As suggested by Öpik (1985), cell wall and membrane folding during drying may be linked to the prevention of tension between the cell membrane and the cell wall. Additionally, filling the intracellular space with vacuoles may also be connected to cellular structure maintenance via preventing cytoplasm retraction, cell membrane detachment, and cell wall collapse (Pampurova and Van Dijck 2014). This mechanism has been described in mesophyll cells of two resurrection plants, Xerophyta humilis and Craterostigma wilmsii. In both species, vacuolization occurred in response to drying and the prevention of cell wall membrane detachment and collapse was associated with this strategy (Farrant 2000).

To sum up, we have explored the dynamics of loss of DT in Leucaena seeds. According to our results, the Leucaena seeds lost the ability to tolerate drying at the end of germination at the point when the embryonic axis started to elongate, and the radicle protruded. The loss of DT was associated with changes in nuclear DNA status in the cells of the radicle. Cells with higher ploidy levels were less tolerant to desiccation. Contrary to what was observed in the Leucaena dry seeds, the intensity and extent of ultrastructural damage observed in the dried germinated Leucaena seeds were severe enough to overcome the resilience of its primary root cells and consequently their ability to resume normal growth. In the future, the pattern of loss of DT observed in the seeds of Leucaena might be used to elucidate structural, biochemical, genetic, and ontogenetic events associated with desiccation sensitivity.

\section{References}

Atif, R.M., Boulisset, F., Conreux, C., Thompson, R., Ochatt, S.J.: In vitro auxin treatment promotes cell division and delays endoreduplication in developing seeds of the model legume species Medicago truncatula. - Physiol. Plant. 148: 549-559, 2013.

Bailly, C.: Active oxygen species and antioxidants in seed biology. - Seed Sci Res. 14: 93-107, 2004.

Baskin, C.C., Baskin, J.M. (ed.): Seeds: Ecology, Biogeography, and Evolution of Dormancy and Germination. - Academic Press, San Diego 1998.

Berjak, P., Pammenter, N.W.: What ultrastructure has told us about recalcitrant seeds. - Rev. bras. Fisiol. veg. 12: 22-55, 2000.
Berjak, P., Pammenter, N.W.: From Avicennia to Zizania: seed recalcitrance in perspective. - Ann Bot. 101: 213-228, 2008.

Bewley, J.D., Black, M. (ed.): Seeds: Physiology of Development and Germination. - Plenum Press, New York 1994.

Bewley, J.D., Bradford, K., Hilhorst, H., Nonogaki, H.(ed.): Seeds: Physiology of Development, Germination and Dormancy. - Springer, New York 2013.

Bino, R.J., Lanteri, S., Verhoeven, H.A., Kraak, H.L.: Flow cytometric determination of nuclear replication stages in seed tissues. - Ann Bot. 72: 181-187, 1993.

Black, M., Corbineau, F., Gee, H., Come, D.: Water content, raffinose, and dehydrins in the induction of desiccation 
tolerance in immature wheat embryos. - Plant Physiol. 120. 463-472, 1999.

Blackman, S.A., Obendorf, R.L., Leopold, A.C.: Maturation proteins and sugars in desiccation tolerance of developing soybean seeds. - Plant Physiol. 100: 225-230, 1992.

Bruggink, T., Van der Toorn, P.: Induction of desiccation tolerance in germinated seeds. - Seed Sci Res. 5: 1-4, 1995.

Buitink, J., Leger, J.J., Guisle, I., Vu, B.L., Wuilleme, S., Lamirault, G., Le Bars, A., Le Meur, N., Becker, A., Kuster, H., Leprince, O.: Transcriptome profiling uncovers metabolic and regulatory processes occurring during the transition from desiccation-sensitive to desiccation-tolerant stages in Medicago truncatula seeds. - Plant J. 47: 735-750, 2006.

Buitink, J., Leprince, O.: Glass formation in plant anhydrobiotes: survival in the dry state. - Cryobiology 48 : 215-228, 2004

Buitink, J., Vu, B.L., Satour, P., Leprince, O.: The reestablishment of desiccation tolerance in germinated radicles of Medicago truncatula Gaertn. seeds. - Seed Sci Res. 13: 273-286, 2003.

Carvalho, C.R., Clarindo, W.R., Praça, M.M., Araújo, F.S., Carels, N.: Genome size, base composition and karyotype of Jatropha curcas L., an important biofuel plant. - Plant Sci. 174: 613-617, 2008.

Cromarty, A.S., Ellis, R.H., Roberts, E.H. (ed.): Design of Seeds Storage Facilities for Genetic Conservation. - IPGRI, Rome 1985.

Dante, R.A., Larkins, B.A., Sabelli, P.A.: Cell cycle control and seed development. - Front. Plant Sci. 5: 493, 2014.

De Castro, R.D., Van Lammeren, Groot, S.P., Bino, R.J., Hilhorst, H.W.: Cell division and subsequent radicle protrusion in tomato seeds are inhibited by osmotic stress but DNA synthesis and formation of microtubular cytoskeleton are not. - Plant Physiol. 122: 327-336, 2000.

Deltour, R. Nuclear activiation during early germination of the higher plant embryo. - J. Cell Sci. 75: 43-83, 1985.

Dinakar, C., Bartels, D.: Desiccation tolerance in resurrection plants: new insights from transcriptome, proteome and metabolome analysis. - Front. Plant Sci. 4: 482, 2013.

Edgar, B.A., Zielke, N., Gutierrez, C.: Endocycles: a recurrent evolutionary innovation for post-mitotic cell growth. Natur. Rev. mol. cell. Biol. 15: 197-210, 2014.

Elmaghrabi, A., Ochatt, S., Rogers, H., Francis, D.: Enhanced tolerance to salinity following cellular acclimation to increasing $\mathrm{NaCl}$ levels in Medicago truncatula. - Plant Cell Tissue Organ Cult. 114 : 61-70, 2013.

Faria, J.M., Buitink, J., Van Lammeren, A.A., Hilhorst, H.W.: Changes in DNA and microtubules during loss and reestablishment of desiccation tolerance in germinating Medicago truncatula seeds. - J. exp Bot. 56: 2119-2130, 2005.

Farrant, J.: A comparison of mechanisms of desiccation tolerance among three angiosperm resurrection plant species. - Plant Ecol. 151: 29-39, 2000.

Hundertmark, M., Buitink, J., Leprince, O., Hincha, D.K.: The reduction of seed-specific dehydrins reduces seed longevity in Arabidopsis thaliana. - Seed Sci Res. 21: 165-173, 2011.

Illing, N., Denby, K.J., Collett, H., Shen, A., Farrant, J.M.: The signature of seeds in resurrection plants: a molecular and physiological comparison of desiccation tolerance in seeds and vegetative tissues. - Integr. Comp. Biol. 45: 771-787, 2005.

Koster, K.L., Leopold, A.C.: Sugars and desiccation tolerance in seeds. - Plant Physiol. 88: 829-832, 1988.
Kranner, I., Birtic, S.: A modulating role for antioxidants in desiccation tolerance. - Integr. Comp. Biol. 45: 734-740, 2005.

Lemontey, C., Mousset-Déclas, C., Munier-Jolain, N., Boutin, J.P.: Maternal genotype influences pea seed size by controlling both mitotic activity during early embryogenesis and final endoreduplication level/cotyledon cell size in mature seed. - J. exp Bot. 51: 167-175, 2000.

Leopold, A.C., Vertucci, C.W.: Membranes, metabolism and dry organisms. - In Leopold, A.C. (ed.): Physical Attributes of Desiccated Seeds. Pp. 23-34, Comstock Publishing, London 1986.

Maia, J., Dekkers, B.J., Provart, N.J., Ligterink, W., Hilhorst, H.W.: The re-establishment of desiccation tolerance in germinated Arabidopsis thaliana seeds and its associated transcriptome. - PLoS ONE 6: e29123, 2011.

Maia, J., Dekkers, B.J.W., Dolle, M.J., Ligterink, W., Hilhorst, H.W.M.: Abscisic acid (ABA) sensitivity regulates desiccation tolerance in germinated Arabidopsis seeds. New Phytol. 203: 81-93, 2014.

Moore, J.P., Vicre-Gibouin, M., Farrant, J.M., Driouich, A.: Adaptations of higher plant cell walls to water loss: drought vs desiccation. - Physiol Plant. 134: 237-245, 2008.

Ochatt, S.: Agroecological impact of an in vitro biotechnology approach of embryo development and seed filling in legumes. - Agron. Sustainable Develop. 35: 535-552, 2015.

Oliver, M.J., Tuba, Z., Mishler, B.D.: The evolution of vegetative desiccation tolerance in land plants. - Plant Ecol. 151: $85-100,2000$.

Öpik, H. The fine structure of some dry seed tissues observed after completely anhydrous chemical fixation. - Ann Bot. 56: 453-466, 1985.

Pampurova, S., Van Dijck, P.: The desiccation tolerant secrets of Selaginella lepidophylla: what we have learned so far? Plant Physiol. Biochem. 80: 285-290, 2014.

Phillips, J.R., Oliver, M.J., Bartels, D.: Molecular genetics of desiccation and tolerant systems. - In Black, M., Pritchard, H.W. (ed.): Desiccation and Survival in Plants: Drying without Dying. Pp 319-341. CABI Publishing, Wallingford 2002.

Potts, M.: Desiccation tolerance of prokaryotes. - Microbiol. Rev. 58: 755-805, 1994.

Rolston, M.P.: Water impermeable seed dormancy. - Bot. Rev. 44: 365-396, 1978.

Saracco, F., Bino, R.J., Bergervoet, J.H.W., Lanteri, S.: Influence of priming-induced nuclear replication activity on storability of pepper (Capsicum annuum L.) seed. - Seed Sci. Res. 5: 25-29, 1995.

Setter, T.L., Flannigan, B.A.: Water deficit inhibits cell division and expression of transcripts involved in cell proliferation and endoreduplication in maize endosperm. - J. exp Bot. 52: 1401-1408, 2001.

Skirycz, A., Claeys, H., De Bodt, S., Oikawa, A., Shinoda, S., Andriankaja, M., Maleux, K., Eloy, N.B., Coppens, F., Yoo, S-D., Saito, K., Inzé, D.: Pause-and-stop: the effects of osmotic stress on cell proliferation during early leaf development in Arabidopsis and a role for ethylene signaling in cell cycle arrest. - Plant Cell 23: 1876-1888, 2011.

Sliwinska, E.: Nuclear DNA replication and seed quality. - Seed Sci Res. 19: 15-25, 2009.

Sliwinska, E.: Cell cycle and germination of fresh, dried and deteriorated sugarbeet seeds as indicators of optimal harvest time. - Seed Sci Res. 13: 131-138, 2003.

Sreedhar, L., Wolkers, W.F., Hoekstra, F.A., Bewley, J.D.: In 
vivo characterization of the effects of abscisic acid and drying protocols associated with the acquisition of desiccation tolerance in alfalfa (Medicago sativa L.) somatic embryos. - Ann Bot. 89: 391-400, 2002.

Tunnacliffe, A., Wise, M.J.: The continuing conundrum of the LEA proteins. - Naturwissenschaften 94: 791-812, 2007.

Verdier, J., Lalanne, D., Pelletier, S., Torres-Jerez, I., Righetti, K., Bandyopadhyay, K., Leprince, O., Chatelain, E., Vu, B.L., Gouzy, J., Gamas, P., Udvardi, M.K., Buitink, J.: A regulatory network-based approach dissects late maturation processes related to the acquisition of desiccation tolerance and longevity of Medicago truncatula seeds. - Plant Physiol. 163: 757-774, 2013.

Vieira, C., Amaral da Silva, E., De Alvarenga, A., De Castro, E., Toorop, P.: Stress-associated factors increase after desiccation of germinated seeds of Tabebuia impetiginosa Mart. - Plant Growth Regul. 62: 257-263, 2010.

Wang, H., Qi, Q., Schorr, P., Cutler, A.J., Crosby, W.L., Fowke, L.C.: ICK1, a cyclin-dependent protein kinase inhibitor from Arabidopsis thaliana interacts with both $\mathrm{Cdc} 2 \mathrm{a}$ and $\mathrm{CycD} 3$, and its expression is induced by abscisic acid. - Plant J. 15: 501-510, 1998. 